\title{
Evaluasi Pembelajaran Tematik Dengan Penilaian Autentik di SDN Pasar Baru 1 Kota Tangerang
}

\author{
Ina Magdalena ${ }^{1}$, Anggun Mila Banowati², Reni Safitri ${ }^{3}$,Eka Nur \\ Wahyuningsih 4 \\ 1,2,3,4. Universitas Muhammadiyah Tangerang \\ email: ${ }^{1}$ inapgsd@gmail.com, ${ }^{2}$.anggunbanowati@gmail.com, ${ }^{3}$ renisafitri198@gmail.com, \\ 4.ekan862@gmail.com ${ }^{4}$
}

\begin{abstract}
The This study aims to obtain comprehensive information about the evaluation of thematic learning by using authentic assessments at SDN Pasar Baru 1 Tangerang City. The findings are as follows: in the thematic learning evaluation activities with authentic assessment the assessment uses the bloom taxonomy contained C1 to C6. In the implementation of authentic learning does not always run smoothly. There are several obstacles including the aspect of the teacher or instructor, there are still some who are less creative in the learning process. This makes the authentic assessment itself difficult to do. To overcome this, the teacher must be equipped with the ability to create more creative and diverse learning methods or media that can make learning more active, thus minimizing the obstacles in authentic assessment.
\end{abstract}

Keywords: learning evaluation, thematic, authentic assessment.

\begin{abstract}
Abstrak
Penelitian ini bertujuan untuk mendapatkan informasi yang komperehensip mengenai evaluasi pembelajaran tematik dengan menggunakan penilaian autentik di SDN Pasar Baru 1 Kota Tangerang. Hasil temuan sebagai berikut : pada kegiatan evaluasi belajar pembelajaran tematik dengan penilaian autentik penilaian nya menggunakan taksonomi bloom yang terdapat $\mathrm{C} 1$ sampai C6. Dalam pelaksanaan pembelajaran autentik tidak selalu berjalan mulus. Ada bebreapa kendala diantaranya yaitu dari aspek guru atau pengajarnya yang masih ada beberapa yang kurang kreatif dalam proses belajar mengajar. Hal ini yang menyebabkan penilaian autentik sendiri sulit dilakukan. Untuk mengatasinya guru harus dibekali kemampuan untuk membuat metode atau media pembelajaran yang lebih kreatif dan beragam yang dapat membuat pembelajaran lebih aktif, sehingga meminimalisir kendala dalam penilaian autentik ini terjadi.
\end{abstract}

Kata kunci: evaluasi pembelajaran, tematik, penilaian autentik. 


\section{PENDAHULUAN}

Pendidikan pada dasarnya merupakan pengembangan holistik pada diri individu yang mencakup aspek fisik, emosional, mental, sosial dan spiritual (Honnutagi, 2011). Istilah holistik mengandung makna menyeluruh atau utuh. Pritscher (2012, p. 138) menyatakan bahwa: "Holistic education is based on the premise that each person finds identity, meaning, and purpose in life through connections to the community, to the natural world, and to spiritual values such as compassion and peace". (Pendidikan holistik didasarkan pada premis bahwa setiap orang menemukan identitas, makna, dan tujuan hidup melalui koneksi kepada masyarakat, dengan alam, dan nilai-nilai spiritual seperti kasih sayang dan perdamaian).

Pembelajaran tematik pada dasarnya adalah model pembelajaran terpadu yang menggunakan tema untuk mengaitkan beberapa mata pelajaran sehingga dapat memberikan pengalaman bermakna kepada siswa ,

Pelaksanaan pembelajaran tematik ini akan memberi beberapa manfaat ,yaitu pertama, dengan menggabungkan beberapa kompetensi dasar dan indikator serta isi mata pelajaran, akan terjadi penghematan, karena tumpang tindih materi dapat dikurangi bahkan dihilangkan. Kedua, peserta didik mampu melihat hubungan-hubungan yang bermakna sebab materi pembelajaran lebih berperan sebagai sarana atau alat, bukan tujuan akhir. Ketiga, pembelajaran $\begin{array}{rcr}\text { Salah } & \text { satu } & \text { bentuk } \\ \text { implementasi } & \text { pendidikan } & \text { holistik }\end{array}$ adalah pembelajaran tematik. Pembelajaran tematik merupakan suatu usaha memadukan pengetahuan secara komprehensif dan terintegrasi. Pembelajaran tematik sebagai salah satu pendekatan integrasi secara alami menghubungkan fakta-fakta dan ideide dalam upaya untuk memahami dunia. Siswa dapat menghubungkan ide-ide dan pengalaman dengan lingkungan tempat tinggalnya melalui jaringan tema. Pembelajaran tematik adalah suatu model terapan pembelajaran terpadu yang mengintegrasikan beberapa mata pelajaran dalam satu kesatuan yang terikat oleh tema (Fogarty, 1991, p. 54). Tema menjadi pengikat keterkaitan antara satu mata pelajaran dengan mata pelajaran lainnya.

dianggap lebih menarik dan bermakna bagi siswa karena model pembelajaran ini menyajikan tematema pembelajaran yang lebih aktual dan konstektual dalam kehidupan sehari-hari (Depdiknas, 2006: 5).

menjadi utuh sehingga peserta didik akan mendapat pengertian mengenai proses dan materi yang tidak terpecah-pecah. Keempat, dengan adanya pemaduan antar mata pelajaran maka penguasaan konsep akan semakin baik dan meningkat (Khummariyatun \& Ismanto, 2018). Adapun keuntungan lain dari pembelajaran tematik bagi siswa dikemuakan oleh Trianto (2011), yaitu pertama,dapat lebih memfokuskan diri pada proses belajar, dari pada hasil belajar. 
Kedua, menghilangkan batas semu antar bagian kurikulum dan menyediakan pendekatan proses belajar yang integratif. Ketiga, menyediakan kurikulum yang berpusat pada siswa yang dikaitkan dengan minat, kebutuhan, dan kecerdasan; mereka didorong untuk membuat keputusan sendiri dan bertanggung jawab pada keberhasilan belajar. Keempat, merangsang penemuan dan penyelidikan mandiri di dalam dan di luar kelas. Kelima, membantu siswa membangun hubungan antara konsep dan ide, sehingga meningkatkan apresiasi dan pemahaman.

Landasan yuridis yang mendasari pelaksanaan pembelajaran tematik di sekolah dasar adalah UU SISDIKNAS tahun 2003 dan UU No. 23 Tahun 2002 tentang Perlindungan Anak dinyatakan bahwa setiap anak berhak memperoleh pendidikan dan pengajaran dalam rangka pengembangan pribadinya dan tingkat kecerdasannya sesuai dengan minat dan bakatnya(Presiden Republik Indonesia, 2003). Dalam UU No. 20 Tahun 2003 tentang Sistem Pendidikan Nasional Bab V Pasal 1-b dinyatakan bahwa setiap peserta didik pada setiap satuan pendidikan berhak mendapatkan pelayanan pendidikan sesuai dengan bakat, minat, dan kemampuannya (Presiden Republik Indonesia, 2003). Hal yang perlu diperhatikan guru dalam mendesain pembelajaran tematik adalah menyusun silabus
Pembelajaran

tematik. Hubungan antara kompetensi dasar, indikator, dan tema pemersatu akan mempermudah guru dalam mengembangkan silabus berdasarkan tema yang dipilih. Dalam hal ini silabus dapat diartikan sebagai rancangan program pembelajaran satu atau sekelompok mata pelajaran yang berisi standar kompetensi dan kompetensi dasar yang harus dicapai, pokok materi yang harus dipelajari siswa, bagaimana cara mempelajarinya dan cara mengetahui pencapaian kompetensi dasar yang telah ditentukan (Sanjaya, 2011).

Diterbitkannya

UU

SISDIKNAS tahun 2003 merupakan titik awal munculnya paradigma baru pendidikan Indonesia. Dalam undang-undang tersebut "proses pengajaran" yang selama ini diterapkan di sekolah dasar diganti dengan "proses pembelajaran", dalam hal ini menggunakan proses pembelajaran tematik (Presiden Republik Indonesia, 2003). Mengacu pada undang-undang tersebut, maka sebagian besar sekolah dasar di Indonesia telah menerapkan pembelajaran tematik dalam kegiatan belajar mengajar di sekolah.

Salah satu penekanan di dalam kurikulum 2013 adalah penilaian autentik. Seperti yang kita ketahui penilaian adalah proses pengumpulan berbagai data yang memberikan gambaran mengenai perkembangan siswa setelah siswa mengalami proses pembelajaran. Penilaian autentik 
adalah kegiatan menilai peserta didik yang menekankan pada apa yang seharusnya dinilai, baik proses maupun hasil dengan berbagai instrumen penilaian yang disesuaikan dengan tuntutan kompetensi yang ada di Standar Kompetensi (SK) atau Kompetensi Inti (KI) dan Kompetensi Dasar (KD) (Kunandar,2013:35-36). Pada penilaian autentik, siswa diminta untuk menerapkan konsep atau teori dalam keadaan sebenarnya sesuai dengan kemampuan atau keterampilan yang dimiliki siswa. Oleh karena itu, guru harus memperhatikan keseimbangan antara penilaian kompetensi sikap, keterampilan dan pengetahuan yang disesuaikan dengan perkembangan karakteristik siswa sesuai dengan jenjangnya. Contohnya untuk PAUD, TK dan SD, lebih banyak porsinya pada soft skill (misalnya kemampuan yang perlu dilatih dan diukur, antara lain: mengamati, motivasi berprestasi, kemauan kerja keras, disiplin, berkomunikasi, tata krama, dll) daripada penilaian hard skill (pengukuran penguasaan pengetahuan dan keterampilan). proses penilaian autentik harus merupakan bagian yang tak terpisahkan dari proses pembelajaran dan mencerminkan masalah dunia nyata/sehari-hari. Sehingga dalam merancang penilaian autentik, perlu memperhatikan prinsip-prinsip, sebagai berikut: penilaian harus menggunakan berbagai ukuran, metode dan kriteria yang sesuai dengan karakteristik dan esensi pengalaman belajar; penilaian harus bersifat holistik mencakup semua aspek dari tujuan pembelajaran (sikap, keterampilan dan pengetahuan).

Menurut Permendikbud, Strandar Penilaian Pendidikan adalah kriteria mengenai mekanisme, prosedur dan instrumen penilaian hasil belajar siswa. Penilaian hasil belajar siswa mencakup kompetensi sikap, keterampilan dan pengetahuan yang dilakukan secara seimbang, untuk mengetahui bahwa setiap siswa sudah sesuai dengan standar yang ditetapkan. Muatan di dalam penilaian antara lain, ruang lingkup materi, kompetensi mata pelajaran/kompetensi.

muatan/kompetensi program dan proses. Prinsip yang paling penting dari penilaian autentik adalah dalam pembelajaran tidak hanya menilai apa saja yang sudah diketahui oleh siswa, tetapi juga menilai apa yang dapat dilakukan oleh siswa setelah pembelajaran selesai. Sehingga kualitas hasil belajar dan kerja siswa dalam menyelesaikan tugas dapat terukur.

Melalui kurikulum 2013 penilaian autentik menjadi penekanan dalam melakukan penilaian hasil belajar siswa yang memperhatikan seluruh minat, potensi dan prestasi siswa secara menyeluruh. Penilaian juga dilakukan secara sistematis dan berkesinambungan agar dapat menggambarkan kemampuan para siswa yang dievaluasi. Sangat penting untuk melibatkan siswa dalam penilaian, sehingga siswa secara sadar dapat mengenali perkembangan 
pencapaian hasil pembelajaran mereka.

\section{METODE PENELITIAN}

\section{Metode yang digunakan} dalam penelitian ini adalah wawancara kepada guru SDN Pasar Baru 1, dimana dilaksanakan tanggal 20 mei 2020 via telephone. Kemudian data akan diolah melalui metode pendekatan kualitatif dengan metode deskripsi, dimana metode ini memusatkan perhatian kepada masalah actual yang sebagaimana adanya pada saat penelitian berlangsung, dalam hal ini peneliti berusaha mendeskripsikan peristiwa dan kejadian yang menjadi pusat perhatian dalam penelitian tanpa memberikan perlakuan khusus terhadap hal tersebut.

Penilitian ini dilakukan dengan tujuan untuk mengetahui evaluasi pembelajaran tematik dengan penilaian autentik yang ada di SDN Pasar Baru 1, sebagaimana evaluasi tersebut telah dilaksanakan pastinya terdapat hambatan dalam pelaksanaannya.

\section{HASIL DAN PEMBAHASAN}

Kami melakukan wawancara kepada salah satu guru SDN Pinang 5 Tangerang, dari hasil wawancara yang telah dilaksanakan maka kami mendapatkan informasi terkait hambatan pelaksanaan evaluasi pembelajaran tematik dengan menggunakan penilaiaan autentik

Hasil yang kami dapatkan adalah evaluasi merupakan proses dimana kita melihat kegiatan siswa selama 6 bulan atau bahkan 1 tahun ajaran dimana siswa dinilai atau di evaluasi kegiatan belajarnya dalam beberapa aspek. Aspek yang pertama yaitu afektifnya, kognitifnya dan psikomotoriknya. Dan jika sudah dievaluasi guru akan mengetahui secara sistematis proses belajar siswa dan kegiatan belajar mengajar mana yang harus dievaluasi, yang harus ditingkatkan dan mana yang harus di hilangkan dalam proses belajar mengajar ataukan metodenya, materi pembelajarannya.

Terdapat perbedaan antara penerapan evaluasi pembelajaran kurikulum 2013 dan kurikulum yang digunakan sebelumnya. Dari mulai perbedaan yang sangat mendasar, contohnya pada kurikulum sebelumnya yaitu KTSP dimana guru yang berperan aktif dalam proses belajar mengajar, dan guru bukan sebagai mentor atau fasilitator. Disini guru sulit untuk menilai atau mengevaluasi proses belajar mengajar karena siswanya kurang aktif di KTSP. Sedangkan pada kurikulum 2013 guru hanya sebagai mentor, fasilitator, dalam proses belajar mengajar. Jadi guru disini sangat mudah untuk mengevaluasi proses belajar mengajar siswa dalam kurikulum 2013, karena siswa yang berperan lebih aktif dalam proses belajar mengajar. Dan juga pada kurikulum 2013 penilaian nya menggunakan penilaian autentik.

$$
\text { Penilaian autentik pada }
$$

Kurikulum 2013 menggunakan taksonomi bloom yang terdapat $\mathrm{C} 1$ sampai C6 dimana C1 yaitu 
pengetahuan, C2 yaitu pemahaman, C3 yaitu pengaplikasian, C4 yaitu analisias, C5 yaitu evaluasi dan C6 yaitu kreasi. Dalam proses pemnbelajaran contohnya pada pelajaran Bahasa Indonesia soal pertama menggunakan C3 yaitu aplikasi disini siswa hanya menemukan masalah, menjawabnya. Nah disini guru mengevaluasi apakah disini ada peningkatan atau tidak ada peningkatan. Kalau tidak ada peningkatan masih tetap menggunaan C3, tetapi jika sudah ada peningkatan disini materi berikutnya guru menggunakan $\mathrm{C} 4$ dan $\mathrm{C} 5$ bahkan C6. Terdapat soal di K13 revisi 2017 sekarang guru dituntut menggunakan soal HOTS (High Order Thinking Skill) jadi tidak boleh menggukana dibawah C4. Semua guru harus menggunakan $\mathrm{C} 4, \mathrm{C} 5$, atau $\mathrm{C} 6$ yaitu analisis, evaluasi atau kreasi. Nah disini siswalah yang berperan sangat aktif dan guru hanya menjadi fasilitator disini. Gunakan dulu C4, jika C4 sudah berhasil gunakan C5 atau C6. Disini siswa akan berpikir tingkat tinggi.

Penerapan evaluasi

pembelajaran tidak selalu berjalan dengan baik, ada beberapa Kendala yang terjadi ketika proses evaluasi pembelajaran dilakukan, diantaranya yang pertama faktor dari sistematis atau faktor dari keguruan nya. Usia guru-guru ini tidak semua relatif usianya muda dan cenderung pembelajarannya monoton dalam kurikulum 2013 dan apalagi sekarang sudah menggunaan tematik dimana semua pembelajaran di mix atau menjadi universal harus saling berkaitan dan bersinergi. Faktor kedua guru kurang kreatif dalam menggunakan metode pembelajaran sehingga tidak membuat siswa terangsang motivasi belajarnya. Faktor ketiga minimnya media pembelajaran yang digunakan oleh guru, yaitu termasuk ke dalam kreatifitas masing-masing guru dalam menggunakan atau membuat media pembelajaran.

Ketika beberapa kendala terjadi pada proses evaluasi, tentunya kami pun mempunyai cara mengetasinya yaitu dengan beberapa cara. Yang pertama, membentuk sebuah tim guru-guru muda untuk mensosialisasikan atau membimbing guru-guru yang usianya sudah lanjut yang tidak mengerti metode pembelajaran yang banyak dan yang kurang kreatif. Bentuk sebuah timnya tidak hanya dari internal, dapat dari eksternal entah itu dari sebuah lembaga, LPMP atapun dinas pendidikan untuk mensosialisasikan membuat seminar kepada guru-guru yang sudah lanjut usia. Kurang lebih seperti itu.

Cara kedua yaitu, pihak sekolah harus dapat memfasilitasi guru dalam menggunakan media pembelajaran. Contohnya, terdapat beberapa sekolah yang tidak ada alat untuk praktikum. Dengan tersedianya media pembelajaran yang lengkap dapat membuat guru lebih kreatif disini guru akan lebih mudah dalam melakukan evaluasi siswa didalam kurikulum 2013 dan kembali lagi ke gurunya harus bisa dan mau belajar 
untuk bisa mengevaluasi pembelajaran di Kurikulum 2013.

\section{SIMPULAN}

Dari hasil penelitian yang sudah kami lakukan maka kami dapat simpulkan bahwa terdapat perbedaan antara penerapan evaluasi pembelajaran kurikulum 2013 dengan kurikulum yang digunakan sebelumnya. Dari mulai perbedaan yang sangat mendasar, contohnya pada kurikulum sebelumnya yaitu KTSP dimana guru yang berperan aktif dalam proses belajar mengajar, dan guru bukan sebagai mentor atau fasilitator. Sedangkan pada kurikulum 2013 guru hanya sebagai mentor, fasilitator, dalam proses belajar mengajar Dan juga pada kurikulum 2013 penilaian nya menggunakan penilaian autentik.

Pada kegiatan evaluasi belajar pembelajaran tematik dengan penilaian autentik penilaian nya menggunakan taksonomi bloom yang terdapat C1 sampai C6. Dalam penlaksanaan pembelajaran autentik ini tidak selalu berjalan mulus. Tentunya ada bebrapa kendala diantaranya yaitu dari aspek guru atau pengajarnya yang masih ada beberapa yang kurang kreatif dalam proses belajar mengajar. Hal ini yang menyebabkan penilaian autentik sendiri sulit dilakukan. Untuk menangani faktor yang menghambat, guru harus dibekali kemampuan untuk membuat metode atau media pembelajaran yang lebih kreatif dan beragam yang daopat membuat pembelajaran lebih aktif, sehingga meminimalisir kendala dalam penilaian autentik ini terjadi.

\section{DAFTAR RUJUKAN}

Arya Setya Nugroho, Nataria Wahyuning Subayani (2019). Pendampingan Lesson Study:Meningkatkan

Pelaksanaan Pembelajaran dengan Pendekatan Scientific Guru SD Muhammadiyah 3 Gresik. Diakses pada 16 Juni 2020. Diakses melalui https://journal.uwks.ac.id/index. php/trapsila/article/view/812

Erni (2016). Evaluasi Pembelajaran Tematik Di Sekolah Dasar Negri 158 Watallipu Kecamatan Donri-Donri Kabupaten Soppeng. Diakses pada 15 Juni 2020. Diakses melalui http://journal.uncp.ac.id

Ina Magdalena, Dias Julianti Agustin (2020). Hambatan dalam Penerapan Teknik Evaluasi Non Tes di SDN Pinang 5 Tangerang. Diakses pada 10 juni 2020 melalui https://ejournal.pamaaksara.org/ index.php/hal/article/view/110

Ina Magdalena, Dita Lutfia Citra Anggraini, Noni Novitasari, Siti Nurlatifah. (2020). Evaluasi Dalam Proses Pembelajaran Tematik Di SDN Kampung Melayu 3 Tangerang. Di akses pada 28 May 2020 . Diakses melalui

https://ejournal.pamaaksara.org/ index.php/hal/article/view/121/ $\underline{97}$

Kementrian Pendidikan Dan Kebudayaan tahun 2013 tentang Konsep Penilaian Autentilk 
Pada Proses Dan Hasil Belajar. Diakses pada 28 May 2020 melalui

https://staffnew.uny.ac.id/uploa d/131570315/pendidikan/PENI LAIAN+OTENTIK+KURIKU LUM+2013.pdf

Magdalena, I., Huliatunisa, Y. (2020). Evaluasi Pembelajaran Sekolah Dasar. Jakarta : FKIP UMT Press

Nur Faqih (2019). Peningkatan Aktivitas dan Hasil Belajar Siswa pada Pembelajaran IPA Materi Gerak Benda Melalui Pendekatan Saintifik. Diakses pada 16 Juni 2020 melalui https://journaluwks.ac.id/index. $\mathrm{php/trapsila/article/view/720}$
Pratiwi Pujiastuti, Sekar Purbarini Kawuryan, Unik Ambarwati (2017). Evaluasi Pembelajaran Tematik Di Sekolah Dasar. Diakses pada 16 Juni 2020 melalui https://journal.uny.ac.id/index.p $\mathrm{hp} / \mathrm{jk} /$ article/download/13035/p df

Sundayana, Wachyu, (2017). Telaah kurikulum \& perencanaan pembelajaran. Jakarta: Erlangga

Tri Sumaharti, H. Marzuki, Sri Utami. 2017. Analisis Evaluasi Pembelajaran Tematik Di Kelas Rendah Sekolah Dasar Negri 1. Diakses pada 5 juni 2020. Dari https://jurnal.untan.ac.id/index. php/jpdpb/article/view/18917 